\section{Ideernes bagmænd}

Preben Hartmann-Petersen, Mendeleev og det periodiske system (2000, 96 sider). Bjarne Kousholt, A. K. Erlang og teletrafikken (2000, 101 sider), H. C. Ørsted og fornuften i naturen (2000, 112 sider); Paul Strathern, Bohr og atomet (1999, 88 sider), Crick \& Watson og DNA-molekylet (1997, 90 sider), Darwin og evolutionen (1999, 87 sider), Einstein og relativiteten (1997, 82 sider), Hawking og de sorte huller (1997, 76 sider), Newton og tyngdekraften (1999, 86 sider). Alle i serien Idéernes bagmænd udgivet af Polyteknisk forlag i Lyngby. Kr. 98,- pr. titel.

Polyteknisk Forlag har lanceret en bogserie, de kalder Idéernes bagmænd. Der er indtil videre kun tre ud af ni bøger med dansk forfatter, men forlaget har annonceret at flere vil følge trop. De øvrige bøger er alle skrevet af den myreflittige Paul Strathern. Ham kan man ikke andet end blive imponeret over. Strathern har i den engelsktalende verden slået sit navn som popularisator fast med de hurtigt læste, underholdende og meget informative filosofi- og videnskabsprimere i serierne The Philosophers in 90 Minutes og The Big Idea: Scientists who Changed the World.

Der er gode grunde til umiddelbart at være skeptisk overfor seriens titel - især den engelske. Kan man isolere og reducere langvarige forskningsprocesser og -traditioner til enkeltpersoners heroiske kamp for at destillere den rene videnskabelige idé? I løbet af de seneste fire årtier er denne type historieskrivning blevet en sjælden vare i den seriøse videnskabshistoriske litteratur. Men man behøver heldigvis ikke være bange for, at Strathern genopliver heltekvadet. Serien giver et godt billede af videnskaben på både godt $\mathrm{og}$ ondt, og formår $i$ de fleste tilfælde at indplacere de portrætterede forskere i en teoretisk, historisk og institutionel sammenhæng. Det er næsten mere end man kan forlange af bøger på denne længde. Men det virker og det hjælper til at give læseren et mere nuanceret billede af naturvidenskaberne.

Strathern er ikke bange for at stoppe op og engagere læseren til kritisk tænkning. I både Bohr og atomet og Crick \& Watson og DNA-molekylet får vi eksempler på, at videnskaben er løbet fra moralen. Vi har knap nok lært at leve med kernefysikkens moralske problemer, der som bekendt kan føre til vor egen udslettelse, før vi i molekylærbiologien får tilegnet os en viden, som vi ikke helt ved, hvordan vi skal bruge. Strathern tøver ikke med at kalde den en farlig viden. Vi kan i dag ændre liv i næsten ubegrænset omfang og det bliver vi nødt til at forholde os til. Det duer ikke at spille uskyldige, lukke øjnene og håbe at tingene nok $\mathrm{i}$ sidste ende vil udvikle sig på passende vis.

Strathern minder os om, at den retning forskningen tager er bestemt af, hvad mennesker vil. Sandhed kan ikke stå uden vilje i moderne naturvidenskab. Men det betyder heldigvis ikke, at vi får tegnet et negativt billede af videnskaberne. Tværtimod. Seriens 
bøger er gennemgående præget af en engagerende entusiasme på videnskabens vegne, uden at der gives køb på den kritiske distance. Samtidig åbnes der for hvordan faktorer som ambitioner, uduelighed, dygtighed, dumhed, drømmeri, held og uheld alle har været medvirkende til at skabe de videnskabelige resultater, som vi kender i dag.

Hvis man har brug for en hurtig introduktion til centrale emner i moderne naturvidenskab og information om nogle af de personer der var med til at skabe den, så er Idéernes bagmænd et godt sted at starte. Man kunne nok have ønsket Ørsted-bogen en mere opmærksom redaktion. Der er ingen undskyldning for at byde læserne sjuskede passager som "Elektrisérmaskinen eller båndgeneratoren, som den også kaldes, findes den dag i dag i ethvert fysiklokale i den danske folkeskole, mange kender den under navnet en båndgenerator"'. Det er dog ikke et generelt problem. Bøgerne er billige, lette at læse og overvejende gode.

Peter C. Kjærgaard

\section{Medicinens historie - herfra hvor vi står \\ Roy Porter, Ve og vel - Medici- nens historie fra oldtid til nutid, Rosinante 2000, 834 sider, 499 kr.}

Den særdeles produktive engelske historiker Roy Porter har fået oversat sit meget roste medicinhistoriske oversigtsværk The Greatest Benefits of Mankind - A Medical History of Humanity from Antiquity to the Pre- sent fra 1997 til dansk, hvor det er blevet givet den lidt skævt rammende titel Ve og vel - Medicinens historie fra oldtid til nutid. Porter, der er professor ved Wellcome Institute for the History of Medicine i London, har i mange år været en markant frontfigur inden for det medicinhistoriske felt, hvilket ikke mindst skyldes hans selvproklamerede forsøg på at redde medicinhistorien fra forskellige antagede helbredssvækkelser. I 1980'erne diagnosticerede han således medicinhistoriens helbred som sygdomsramt og identificerede de mest alvorlige sygdomme som scientisme (reduktion af medicinens historie til lægevidenskabens historie) og presentisme eller positivisme (rekonstruktion af medicinens historie som en kumulativ fremskridtsproces hen imod det aktuelle niveau). Ikke mindst havde det medicinhistoriske felt i mange år fungeret som et forholdsvist internt anliggende for lægevidenskaben, hvilket kom til udtryk ved, at medicinens historie blev fortalt med udgangspunkt i den aktuelle lægevidenskab, der blev fremstillet som det foreløbige resultat af en simpel fremskridtsproces, der bestod i de store lægers vedvarende heroiske kamp imod fortidens falske teorier og inadækvate metoder. Til bekæmpelse af denne sygdom udkastede Porter så en effektiv terapi, der skulle bestå i en socialhistorisk inspireret medicinhistorie, hvis intention var at beskrive medicinens historie som en kompleks proces, der var indflettet $\mathrm{i}$ en bredere samfundsmæssig, social og kulturel kontekst.

Denne videnskabsteoretiske intention genfindes i høj grad i Ve og 